\title{
Accounting Education Change, Information Technology, And Curriculum Integration
}

George Joseph, (E-mail: josephg@tigerpaw.savstate.edu), Savannah State University Asha George, (E-mail: ageorge@tigerpaw.savstate.edu), Savannah State University

\begin{abstract}
This paper traces the progression of emphasis on information technology in recent reports calling for accounting change culminating in the call for integration of accounting curricula with information systems (IS). Using existing curricular integration frameworks, two trajectories for IS-accounting curricula integration, Information Systems auditing and Technology Management, are developed. Existing accounting curricula did not exhibit a definite framework, but some curricula tended to fall within the frameworks outlined above. Additionally, ITrelated courses appear to either be "outsourced" or "internally generated", the latter involving intrinsic IT-related changes in the content of traditional subjects.
\end{abstract}

\subsection{Introduction}

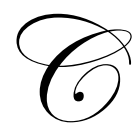

hanges in technology have changed the fundamental nature and content of several tasks within organizations, and information tools created by technology have also substantially altered other facets of accounting, such as financial reporting and career opportunities. For instance, Wallman (1997) points out that increased speed and access to information has increased expectations of accounting and questioned the relevance of information that is prepared quarterly or even monthly. This has resulted in shifts in demands made on accountants. For example, there has been a shift in the role of the accountant from preparers of accounting statements to business partners, consultants and "knowledge workers" (Beresford and Johnson 1995; Siegel and Kulesza 1996). The reports point out that it is imperative for accounting educators to rise to the challenge posed by information technology (IT). But the content of accounting curricula has not changed sufficiently to reflect these aspects.

The dramatic changes in IT and in the business environment have educators predicting a "perilous future" for accounting (e.g., Albrecht and Sacks 2000). Warnings of the deterioration have been sounded over a period of time beginning with the American Accounting Association's Bedford Committee that first alerted accounting academics about the problem in pedagogy and several subsequent reports. The intrinsic relationship between IT and accounting is recognized in most of these studies. Recent reports emphasize greater integration of accounting curriculum with other areas, particularly information systems. Albrecht and Sacks (2000), for example, suggest that a combination of traditional accounting courses and information systems courses is one strategy to counter the uncertain and changing environment for accounting education. The Information Systems Audit and Control Association (ISACA) have provided a model curriculum for such integration. The Certified Information Technology Professional (CITP) designation provided by the AICPA provides an alternate view of possible course mixes for such an integrated curriculum.

To understand the nature and extent of integration of IT and accounting, this paper examines several accounting curricula to determine the presence and extent of integration. Specifically, course mixes are examined from two perspectives to provide insights into the possible options in such an integrated curriculum. First, the course mix is analyzed for frequency and nature of course occurrence. A small proportion of accounting programs were found to have created a track that integrated IT and accounting areas, consistent with Albrecht and Sacks (2000). These institutions adopted one of two approaches to creating the integrated curriculum, either "outsourcing" courses from the IS area or "internally generating" IT-intensive courses in accounting areas. The latter approach was a more in-depth ap- 

stage in the evolution of information systems in academe, where there is a shift of content to functional areas, thereby diminishing the dominance of a separate information systems area. Next, the course mixes are also analyzed from the perspective of career paths based on the frameworks provided by the ISACA model leading to areas covered by the Certified Information Systems Auditor (CISA) certification, and the other emphasizing IT strategic planning and the management of IT, which is the focus of the Certified Information Technology Professional (CITP) designation provided by the AICPA.

The next section summarizes curriculum change issues recorded in the accounting education change reports, followed by a review of the frameworks for curricular integration. This is followed by an examination of a number of accounting programs and their approach to integrating IT into the curriculum in light of curricular issues described earlier. The integrated curricula are further analyzed by frequency of course occurrence and by career path outlined by the curricular frameworks. Finally, the paper analyses these results in the light of the general trends in IT, and provides conclusions.

\subsection{The Need for Curriculum Integration}

To understand the relationship between accounting education and information systems, it is useful to review various perspectives in the reports on accounting education (see the Appendix for a timeline that also tries to capture highlights of the various reports). The earliest of the reports, the Bedford Report (1986), evaluated the current state of accounting education and pointed out that several new accounting courses, including the systems course had been increasingly included in accounting curriculums. This study was closely followed by the White Paper in 1989 sponsored by the then Big 8 accounting firms. The report expressed concerns over the current state of accounting education.

Weakness in accounting education has a direct impact on the skills and knowledge acquired by accounting graduates. This is evident from the IMA sponsored surveys investigating perspectives of corporate employers as well as employees to determine accounting skills and knowledge areas (AKSAs) that are important for management accounting in the current environment (Siegel and Sorensen 1994; Seigel and Kulesza 1996). In reviewing the employees' perspective (referred to as practice analysis), Siegel and Kulesza (1996) stress the role of information systems and IT as key catalysts behind the impetus for change. There is indication that there are weaknesses in several of the skills required in the changing environment, such as the use of computerized spreadsheets and systems, knowledge of the business and familiarity with business processes, besides writing, listening and speaking/presentation skills that were among the most important AKSAs revealed by the survey. The accountant in the new environment is a communicator, conveying information from a variety of sources with clarity, conciseness and precision.

Despite these evidences, a subsequent report (the AAA's Changing Environment Committee 1998) notes that academe has not exploited the opportunities provided by IT. They point out that, "business schools are behind in adopting IT into their programs. Schools fall short in the use of IT, both as an integrative mechanism across the curriculum and as a delivery method for serving students, any time, any place" (pp. 4). This report further emphasizes the importance of accounting having an integrative view with other disciplines such as systems. They point out that "programs that foster an integrative view of how accounting interfaces with other functional areas of business will be more successful than those with a narrow accounting focus. For example, it is imperative that accountants have a strong systems background. Systems knowledge that formerly was considered a desirable quality is now an essential quality" (pp. 5).

Subsequent reports directly and indirectly suggest the need for integration. The results of Albrecht and Sacks (2000)'s investigations caused them to conclude that it was even more critical to understand how IT had "reshaped everything we do". One strategy they suggested was combining accounting with information systems. This was based on the premise that accounting education needs to broaden its understanding of what accounting is, and see it as a subset, and extension of, the larger business information system. "With a broadly defined "information" perspective of accounting, it is logical that accounting education would evolve as a combination of traditional accounting courses and information systems courses. Such a strategy would require a reduced amount of time and 

depth devoted to traditional accounting and more study of information systems" (pp. 62). Williams (2000) mentions integration as one of the challenges facing accounting education, which he points out is "arguably our biggest challenge, but one that, if met, may pay the richest dividends" (pp. 68).

\subsection{Curricular Integration Design Frameworks}

To provide legitimacy and direction to an integrated curriculum, they must adapt to a framework that convinces the principle stakeholders, employers and students, that the program has validity and prepares students for definite career paths. Two integrated curriculum frameworks available for benchmarking include the pro forma curriculum design provided by the Information Systems Audit and Control Association (ISACA) that prepares students for a career in IS Audit, and the second adapted from the program for Certified Information Technology Professional (CITP), sponsored by the AICPA, which enable accountants to develop knowledge to manage IT and operate effectively in the changing technological environment.

The ISACA have recommended model curricula for the graduate and undergraduate levels to meet the needs and expectations of the IS auditing profession. Bodnar (1999) reports that the ISACA issued a document in March 1998 entitled "Model Curricula for Information Systems Auditing at the graduate and undergraduate levels". The ISACA have developed the model curricula for the graduate and undergraduate levels and state that they are based on "the needs and expectations of the IS auditing profession and the prior research of academicians, practitioners, audit organizations, and professional societies". The IS auditors provide a specific undergraduate model curriculum that blends three knowledge areas, namely Accounting, Information Systems, and Internal Auditing. ISACA suggests three knowledge areas (Accounting, Information Systems, and Auditing) in their proforma curriculum. The Accounting Group consists of 5 courses namely Accounting Principles I, Accounting Principles II, Intermediate Accounting I or Management Accounting, Process Control/Internal Control, and Accounting Information Systems. The Information Systems Group consists of Introduction to Computers, Systems Analysis and Design, Data Base Management Systems, Computer-based Communication Networks, and Management of Information Systems. Finally, the Auditing Group consists of Internal Auditing I, Introduction to Information Systems Auditing/CAATs, Special Topics (e.g., IS Integrity and Confidentiality, Audit Ethics). The courses prepare students for the examinations of the relatively new certification in Information Systems Auditing, namely Certified Information Systems Auditor (CISA). The flow and sequence of the courses are also provided to guide structuring of the courses.

The AICPA has also understood the critical nature of IT and has established an accreditation program for CPAs involved in information technology strategic planning, implementation, management and business strategies for information systems. Individuals who meet the criteria are awarded the Certified Information Technology Professional (CITP) designation. The CITP serves as the "bridge between business and technology, leveraging the CPA's strategic and general business skills" (CITP Designation Handbook). To be awarded the CITP, the CPA has to acquire a total of 100 points from three areas, business experience, life long learning and an examination. Business experience is required in areas that include Information Technology Strategic Planning, Information Systems Management, Systems Architecture, Business Applications and E-business, and Systems Auditing and Internal Control. The CITP exam emphasizes the same areas, but the proportion varies, with Information Technology Strategic Planning (18\%), Information Systems Management (15\%), Systems Architecture (11\%), Business Applications and Ebusiness (18\%), Security, Privacy and Contingency Planning (11\%), Systems Development, Acquisition and Project Management (13\%), Databases and Database Management (8\%), and Systems Auditing and Internal Control (8\%). This provides the second framework for integrating information systems and accounting as it reflects the AICPA vision of the emerging role of the CFO and the financial professional and is succinctly summarized by Dickson (2001): "According to the CPA vision, it is the responsibility of the financial professional to move up the value ladder by constantly participating in activities that add value to the CFO role. Today's CFOs clearly must do more than the status-quo to retain the survivor trophy, especially as this role relates to technology management" (pp.27). Table 1 provides an overview of the two frameworks. 


\begin{tabular}{|l|l|l|}
\hline \multicolumn{1}{|c|}{ CISA } & Frameworks 1 - Frameworks for AIS Integration \\
\hline Process Control/ Internal Control & & CITP \\
\hline Accounting Information Systems & & Information Systems Management \\
\hline Intro. to Systems Analysis and Design & & Systems Architecture \\
\hline Data Base Management Systems & & Business Applications and E-business \\
\hline Computer-based Communication Networks & & Security, privacy and contingency planning \\
\hline Computer-based Communication Networks & & Systems Development, Acquisition and Project Management \\
\hline Management of Information Systems & & Databases and Data Base Management \\
\hline Internal Auditing I & & Systems Auditing and Internal Control \\
\hline $\begin{array}{l}\text { Introduction to Information Systems Audit } \\
\text { ing/CAATs }\end{array}$ & & \\
\hline $\begin{array}{l}\text { Special Topics } \\
\text { (e.g., IS Integrity and Confidentiality) }\end{array}$ & & \\
\hline
\end{tabular}

To summarize, the two frameworks focus on the two critical areas of integration for the accountant, the auditing of computerized systems, and the increasing sophistication in managing IT required of accountants in industry. In the first role, the accountant is required to understand the IT integrated accounting systems and be able to audit them. This prepares them to provide support services to the internal and external auditors in evaluating controls and the reliability of information systems. The second role of the accountant is to be able to plan and manage complex information technologies in industries that apply them to a variety of platforms, including e-business and may encompass such areas as Systems Analysis, Design and Implementation, ERP, and E-business. This prepares accountants to provide support services to the financial accountant and CFO in their emerging role of managing and integrating IT into business decisions. The knowledge and skills are so diverse and specialized that the body of knowledge can be separately treated. They also form the basis for development of curriculum in accounting programs that seek to integrate the accounting and information systems areas.

The next section examines some of the accounting curricula to understand the nature and extent of integration of IT into accounting programs.

\subsection{Examination of Accounting Curricula}

Of the 379 AACSB International accredited US business schools (as of September 2001, when this dataset was updated), a sample of 175 undergraduate accounting programs (AP) was selected. The sample was grouped by size (with intervals of 5000 undergraduate students between each group, classified for convenience into four categories, "Small", "Mid-size", "Large" and "Very large") and on the basis of integration of accounting curricula with IT. The size classification was made to reveal whether variations between schools may be associated with size and therefore, resource availability. The results of the selection are shown in Table 2. The data was collected from the college Web sites. 
Table 2 - Summary of Accounting Programs' Sample

\begin{tabular}{|l|c|c|c|c|c|c|c|c|}
\hline $\begin{array}{l}\text { Full-time } \\
\text { UnderGraduate } \\
\text { Enrollment }\end{array}$ & $\begin{array}{c}\text { Popula- } \\
\text { tion }\end{array}$ & $\begin{array}{c}\text { Sample } \\
\text { Total }\end{array}$ & $\begin{array}{c}\text { No AIS } \\
\text { Courses/Major } \\
\text { s }\end{array}$ & $\begin{array}{c}\% \text { of } \\
\text { Sample }\end{array}$ & $\begin{array}{c}\text { AIS Courses } \\
\text { Only }\end{array}$ & $\begin{array}{c}\% \text { of } \\
\text { Sample }\end{array}$ & $\begin{array}{c}\text { AIS majors/ } \\
\text { concentrations }\end{array}$ & $\begin{array}{c}\% \text { of } \\
\text { Sample }\end{array}$ \\
\hline $\begin{array}{l}\text { Less than } 5000 \\
\text { (Small) }\end{array}$ & 109 & 47 & 18 & $38.30 \%$ & 27 & $57.45 \%$ & 2 & $4.26 \%$ \\
\hline $\begin{array}{l}5000-10000 \\
\text { (Mid-size })\end{array}$ & 124 & 58 & 10 & $17.24 \%$ & 44 & $75.86 \%$ & $4^{\mathrm{a}}$ & $6.90 \%$ \\
\hline $\begin{array}{l}10000-15000 \\
\text { (Large) }\end{array}$ & 68 & 38 & 1 & $2.63 \%$ & 28 & $73.68 \%$ & 9 & 23.68 \\
\hline $\begin{array}{l}\text { Greater than } \\
\begin{array}{l}15000 \text { (Very } \\
\text { Large) }\end{array}\end{array}$ & 57 & 32 & 5 & $15.63 \%$ & 24 & $75.00 \%$ & 3 & $9.38 \%$ \\
\hline
\end{tabular}

Examination by integration with IT suggested that there were three levels of integration. 19.4 percent of the total (34 APs) of the sample did not appear to have made any noticeable changes in the accounting curriculum in response to the IT trends. The majority of this category (about 53\%) was among the "small" institutions. 70 percent of the sample (113 APs) had required an Accounting Information Systems (AIS) course in the accounting curriculum. 10.3 percent of the sample (the remaining 18 APs, listed in Appendix) had provided the option to concentrate or major in the Accounting Information Systems area. The majority (50\%) in this category appeared in the "large" institution category $(10,000-15,000)$.

\subsection{Analysis and Insights from Curriculum Integration}

\subsection{Analysis by nature and frequency of course mix}

This section reviews the nature and frequency of courses within the course mixes.

The courses are classified based on course title, and further analyzed in Table 3. The table provides the course mix in the accounting and information systems areas. The accounting courses include several traditional and some specialized courses as well. In order of frequency, the accounting courses include Intermediate Accounting I (16), Accounting Information Systems (14), Managerial Accounting (11), Auditing (11), Intermediate Accounting II (11), Taxation (8), and Information Technology Auditing (7). The most popular elective was Taxation (6), followed by Managerial Cost Accounting and Accounting Internship Project (4). In the CIS area, the course categories include Database Design (10), Systems Analysis and Design (8), Programming languages (7, which includes a variety of languages), Networking and Telecommunication, Expert Systems, and E-commerce and Cyber law. Several APs offered electives, the most popular among which was Data Communications, Networking and Telecommunications (6), and Expert Systems, Decision Support Systems (3).

Of particular interest are the specialized courses with information technology intensity, Information Technology Auditing being the most frequently required (7). Other "IT Intensive" Accounting courses included AIS Network Environment and Controls, AIS Risk Assessment, IT Evaluation and Controls, SAP Accounting Evaluation and Control, SAP Accounting Applications, Plan/Control/Performance Evaluation using ERP, Accounting Technology, Advanced System Technology for Accountants. In view of Arnold and Sutton (2001), these specialized courses may indicate a stage in the evolution of information systems in academe, where there is a shift of content to functional areas, thereby diminishing the dominance of a separate information systems area. Specifically, they state that "while the domain is young and the research still striving to mature, the domain is growing and beginning to demand attention" (pp. 142). They further prognosticate that eventually IS will lose their dominance as a standalone domain, being supplanted by the functional areas such as accounting and marketing, as technology becomes easier to integrate

\footnotetext{
${ }^{a}$ Information about the course mix of one university was not available from their Web site, nor was there any response to a request for curriculum.
} 
into these areas. From this perspective, we may conclude that the "outsourced" courses in information systems from the IS Departments may be one stage before a more complete transition to "internally generated" courses that provide the depth of technology while integrating with essential features of that functional area.

Providing the break-up of course mixes by size indicate that curriculum integration occurs at all levels of accounting programs, though with some minor variations. For example, the "small" category does not have Intermediate Accounting II, and it occurs less frequently in "large" than the others. Four institutions in the "large" category institutions and one in the small were also found to have had developed new courses to effectively integrate Information Systems with Accounting. However, there are consistencies among the curricular structures. The common elements are the inclusion of an Intermediate and AIS course in almost all the programs.

Comparison of the course mix with the model curricula developed by the IASCF also suggests some common areas. For example, the Intermediate, Cost Accounting, Audit, Database Management, and Systems Analysis courses appear in the IASCF course mix. However, other courses in the information systems area (i.e., Communications Networks and Management of Technology) occurred less frequently among the sample of accounting programs. 


\begin{tabular}{|c|c|c|c|c|c|c|c|c|c|c|c|c|c|c|c|c|c|c|c|c|}
\hline & \multicolumn{10}{|c|}{ Required Courses } & \multicolumn{10}{|c|}{ Elective Courses } \\
\hline & \multicolumn{5}{|c|}{ Basic } & \multicolumn{5}{|c|}{ Advanced/Level II } & \multicolumn{5}{|c|}{ Basic } & \multicolumn{5}{|c|}{ Advanced/Level II } \\
\hline & $\mathrm{S}$ & $\mathrm{M}$ & $\mathrm{L}$ & VL & Total & $\mathrm{S}$ & M & $\mathrm{L}$ & VL & Total & $\mathrm{S}$ & M & $\mathrm{L}$ & VL & Total & $\mathrm{S}$ & $\mathrm{M}$ & $\mathrm{L}$ & VL & Total \\
\hline Total Colleges in Sample & 2 & 3 & 9 & 3 & 17 & 2 & 3 & 9 & 3 & 17 & 2 & 3 & 9 & 3 & 17 & 2 & 3 & 9 & 3 & 17 \\
\hline \multicolumn{21}{|l|}{ Accounting Areas: } \\
\hline Intermediate Accounting $^{\mathrm{a}}$ & 2 & 3 & 8 & 3 & 16 & & 3 & 5 & 3 & 11 & & & & & 0 & & & & 1 & 1 \\
\hline Accounting Information Systems ${ }^{\mathrm{b}}$ & 1 & 2 & 9 & 2 & 14 & 1 & 1 & 2 & & 4 & & & & & 0 & & & & 1 & 1 \\
\hline Auditing $^{\mathrm{c}}$ & 1 & 2 & 6 & 2 & 11 & & & & & 0 & & & 1 & 1 & 2 & & & & & 0 \\
\hline Managerial Cost Accounting & 1 & 3 & 5 & 2 & 11 & & 1 & & & 1 & & 1 & 1 & 1 & 3 & & & & 1 & 1 \\
\hline Taxation & & 2 & 5 & 1 & 8 & & & & & 0 & & & 2 & 2 & 4 & & 1 & & 1 & 2 \\
\hline Information Technology Auditing $^{\mathrm{d}}$ & 1 & 1 & 4 & 1 & 7 & & & & & 0 & & & 1 & 1 & 2 & 1 & & & & 1 \\
\hline IT intensive Accounting courses $^{\mathrm{e}}$ & 1 & & 4 & & 5 & & & 1 & & 1 & & & & & 0 & & & & & 0 \\
\hline Accounting Internship/Project $^{f}$ & & 1 & 3 & 1 & 5 & & & & & 0 & 1 & & 1 & 1 & 3 & & 1 & & & 1 \\
\hline Other $^{\mathrm{g}}$ & 1 & & 2 & 2 & 5 & & & & & 0 & & & 1 & 2 & 3 & & 1 & & & 1 \\
\hline \multicolumn{21}{|l|}{ CIS Areas: } \\
\hline Programming Principles $^{\mathrm{h}}$ & 1 & 1 & 2 & & 4 & & & & & 0 & & & 1 & & 1 & & & & & 0 \\
\hline Programming languages & 2 & 1 & 3 & 1 & 7 & & & & & 0 & 1 & 1 & & 1 & 3 & 1 & & & 1 & 2 \\
\hline Database Design & 2 & 2 & 5 & 1 & 10 & & & & 1 & 1 & & & & 1 & 1 & & & & & 0 \\
\hline Systems Analysis, Design, Devpt & 1 & 1 & 4 & 2 & 8 & & & & & 0 & & & 1 & 1 & 2 & & 1 & & & 1 \\
\hline Data Communications ${ }^{\mathrm{i}}$ & & & 1 & 1 & 2 & & & & & 0 & 2 & 1 & 2 & 1 & 6 & & 1 & & & 1 \\
\hline Expert Systems, DSS, ERP & & & 1 & & 1 & & & & & 0 & & 1 & 1 & 1 & 3 & & 1 & & & 1 \\
\hline E-Commerce, Cyberlaw & & & 1 & & 1 & & & & & 0 & 1 & & & & 1 & & & & & 0 \\
\hline IS Project/Internship $^{j}$ & & & & & 0 & & & & & 0 & 1 & 1 & & & 2 & & & & & 0 \\
\hline Other $^{\mathrm{k}}$ & & & 2 & 2 & 4 & & & & & 0 & 1 & 1 & & 1 & 3 & & 1 & & & 1 \\
\hline
\end{tabular}

${ }^{a}$ Intermediate Accounting includes Financial Reporting

${ }^{\mathrm{b}}$ AIS includes Accounting Information Systems, Accounting Systems, AIS Design, AIS Development

${ }^{c}$ Auditing includes Auditing, Auditing \& Assurance, Financial Auditing, Operational Auditing, Internal Auditing, Auditing Theory \& Practice

${ }^{\mathrm{d}}$ IT Auditing includes Auditing issues in Ecommerce, EDP Auditing

${ }^{\mathrm{e}}$ IT intensive Accounting courses include AIS Network Environment and Controls, AIS Risk Assessment, IT Evaluation \& Control, SAP Accounting Applications, Plan/control/Performance

Evaluation using ERP, Accounting Technology, Advanced System technology for Accountants

${ }_{\mathrm{f}}^{\mathrm{f}}$ Accounting Project/Internship includes Projects, Internships, Project Implementation, Applied Software Development Project

${ }^{\mathrm{g}}$ Other areas in Accounting include: Fundamentals of Accounting, Advanced Accounting, Fund Accounting, Governmental and Not-for-Profit Accounting, International Acctg., Accounting

Theory, Business Analysis for Accountants, Internal \& External Financial Reporting Issues, Personal Financial Planning, Law for Accountants, Accounting Policy

${ }^{\mathrm{h}}$ Programming principles includes Data abstractions, data structures, programming principles

${ }^{i}$ Data Communications includes Data communications, networking, telecommunications

${ }^{\mathrm{j}}$ IS Project/Internship includes Projects, Internships, Project Management, Project Design \& Implementation

${ }^{\mathrm{k}}$ Other areas in CIS include: RAD technology, Business systems applications, Special Topics in IS, Distributed systems, Business Applications of Computers, Management/Business Information Systems, Advanced Data Management Technology, Microcomputers in Business 


\subsection{Analysis by career path}

The information systems component of the "information systems and accounting integration" strategy is further analyzed from the perspective of the career paths provided by the CITP and CISA frameworks. The first is along the audit path leading to areas covered by the emerging Certified Information Systems Auditor (CISA) certification. The second path emphasizes IT strategic planning and the management of technology, covering areas similar to those covered under the Certified Information Technology Professional (CITP) designation provided by the AICPA. Table 4 provides the two frameworks and the information systems components of selected accounting programs that are aligned to one or the other of the frameworks to illustrate the use of this framework. San Jose State and Bowling Green, for example, are aligned to the CISA framework, whereas Chico is seen to be closer to the CITP framework. Bentley has developed a curriculum that allows students to choose between the two frameworks.

The IT Audit curriculum provided by ISACA is audit intensive (about $48 \%$ of course content) and includes an overview of information systems architecture and management. It is found that some programs went beyond merely using traditional courses by developing courses that had greater depth to this area, for example, Information Systems Auditing and Control and Audit Issues in E-Commerce. The increasing depth in the courses also suggests that IT has created intrinsic changes in the nature of some traditional courses. The general focus of the curriculum is to prepare students to be effective in the emerging audit and assurance of information systems and to be prepared to take the CISA examinations. Bowling Green State University, for example, which provides the Information Systems Auditing and Control course, along with a mix of accounting and information systems courses highlights their strategy as follows: "Career opportunities within organizations or as consultants providing computer audit assurance services are abundant. While certification as a CISA Auditor requires work experience, graduates from this program are expected to be well qualified to take the CISA examination. Employer interest in the program is extremely high as very few programs capable of producing graduates qualified to provide computer audit assurance services exist at present" [On-line]. The Bowling Green Accounting curriculum seems to be modeled along the lines of ISACA curriculum, having two upper level courses in auditing (including Information Systems Auditing and Technology). However, there were variations, with fewer than the recommended four audit-related courses.

The second framework emphasizes the management of IT, with over $60 \%$ of content related to IT Strategic Planning, Systems Management, Systems Development and Project Management. It also includes components of Systems Architecture, E-business and Database Management Systems, besides a relatively small component of Systems Auditing and Security. Programs following this strategy encompass a wide variety of areas such as Systems Analysis (for example, by providing a CASE development course such as Rapid Application Development Technology) that provide the AIS major opportunities as consultants or systems analysts, and Business-to-Business integration, which combined with ERP, value-chain analysis and the capabilities of decision support systems provide valuable tools for management information and decision-making. The California State University (Chico) curriculum models one version of curriculum that emphasizes this aspect. Their curriculum includes three ERP courses (SAP Accounting Applications, Plan/Control/Performance evaluation using ERP, and ERP: Systems Configuration and Use) and other related courses. Because of the wide variations that are possible along this framework (for example, Networking, Management of Technology and Database Management Systems, besides ERP), most programs adopt this path, as there are more creative options available on this path and include the possibility of availing of the resources of the Information Systems Department.

The variations in the integration of information systems and accounting indicate that the re-structuring programs in responses to IT are consistent with approaches suggested by Albrecht and Sacks (2000) based on AACSB guidelines. Specifically, they agree with the AACSB conclusions that each school or department must decide for itself what its mission is, and then establish a strategic plan to achieve that mission. "We need to accept that (i.e., the AACSB) philosophy and implement it, both in fact and in spirit. Many of our focus-group participants bemoaned the prevalence of the cookie cutter approach we have followed in developing accounting curricula.... There is no one model or prescription that all schools should adopt to resolve the crisis we face in accounting education. Faculty in each department must decide for themselves what their response will be." (pp. 60). 
Table 4 - Curriculum Integration Framework Alignment Sample

\begin{tabular}{|c|c|c|c|c|c|}
\hline $\begin{array}{l}\text { CISA (IS Audit } \\
\text { Career Path) }\end{array}$ & $\begin{array}{l}\text { San Jose } \\
\text { Univ }\end{array}$ & Bowling Green & Bentley & Cal.State Chico & $\begin{array}{l}\text { CITP (IS Man- } \\
\text { agement Career } \\
\text { Path) }\end{array}$ \\
\hline $\begin{array}{l}\text { Intro. to Systems } \\
\text { Analysis \& De- } \\
\text { sign }\end{array}$ & $\begin{array}{l}\text { Intro to Sys } \\
\text { Analysis \& } \\
\text { Design }\end{array}$ & $\begin{array}{l}\text { Systems Analy- } \\
\text { sis \& Design }\end{array}$ & $\begin{array}{l}\text { Analysis, Mod- } \\
\text { eling \& Design } \\
\text { Applied Soft- } \\
\text { ware Project } \\
\text { Mgnt }\end{array}$ & $\begin{array}{l}\text { Structured Systems } \\
\text { Analysis }\end{array}$ & $\begin{array}{l}\text { Systems Devel- } \\
\text { opment, Acquisi- } \\
\text { tion and Project } \\
\text { Management } \\
(13 \%)\end{array}$ \\
\hline $\begin{array}{l}\text { Data Base Man- } \\
\text { agement Systems }\end{array}$ & & $\begin{array}{l}\text { Database Man- } \\
\text { agement }\end{array}$ & $\begin{array}{l}\text {-Data mgnt with } \\
\text { SQL } \\
\text {-Adv. Data Mgnt } \\
\text { techonology }\end{array}$ & Database design & $\begin{array}{l}\text { Databases \& Da- } \\
\text { ta Base Manage- } \\
\text { ment }(8 \%)\end{array}$ \\
\hline $\begin{array}{l}\text { Computer-based } \\
\text { Communication } \\
\text { Networks }\end{array}$ & $\begin{array}{l}\text { AIS Net- } \\
\text { work Envi- } \\
\text { ronment \& } \\
\text { Controls }\end{array}$ & $\begin{array}{l}\text { Business Data } \\
\text { Communication } \\
\text { \& Distributed } \\
\text { Processing }\end{array}$ & $\begin{array}{l}\text { Computer Net- } \\
\text { works }\end{array}$ & & $\begin{array}{l}\text { Systems architec- } \\
\text { ture }(11 \%)\end{array}$ \\
\hline $\begin{array}{l}\text { Management of } \\
\text { Information Sys- } \\
\text { tems }\end{array}$ & & & & & $\begin{array}{l}\text { Information sys- } \\
\text { tems manage- } \\
\text { ment (15\%), }\end{array}$ \\
\hline $\begin{array}{l}\text { Process Control/ } \\
\text { Internal Control }\end{array}$ & $\begin{array}{l}\text { Security, } \\
\text { controls \& } \\
\text { audit issues } \\
\text { in E- } \\
\text { Commerce }\end{array}$ & $\begin{array}{l}\text { IS Auditing \& } \\
\text { Control }\end{array}$ & & & $\begin{array}{l}\text { Systems Auditing } \\
\text { and Internal Con- } \\
\text { trol (8\%) }\end{array}$ \\
\hline $\begin{array}{l}\text { Accounting In- } \\
\text { formation Sys- } \\
\text { tems }\end{array}$ & AIS & AIS & $\begin{array}{l}\text { - AIS } \\
\text { - Adv.AIS }\end{array}$ & AIS & \\
\hline $\begin{array}{l}\text { Introduction to } \\
\text { Information Sys- } \\
\text { tems Auditing/ } \\
\text { CAATs }\end{array}$ & $\begin{array}{l}\text { AIS Risk } \\
\text { Assessment }\end{array}$ & & $\begin{array}{l}\text { - IT Auditing } \\
\text { - Adv.IT Auditing }\end{array}$ & & \\
\hline \multirow[t]{4}{*}{$\begin{array}{l}\text { Special Topics } \\
\text { (e.g., IS Integrity } \\
\text { and Confidentiali- } \\
\text { ty }\end{array}$} & $\begin{array}{l}\text { Current top- } \\
\text { ics in IT au- } \\
\text { diting }\end{array}$ & & RAD technology & & \\
\hline & & & & & $\begin{array}{l}\text { Security, privacy } \\
\text { and contingency } \\
\text { planning }(11 \%)\end{array}$ \\
\hline & & & & $\begin{array}{l}\text { Plan/ Control/ Per- } \\
\text { formance Eval.using } \\
\text { ERP }\end{array}$ & $\begin{array}{l}\text { Information } \\
\text { Technology Stra- } \\
\text { tegic Planning } \\
(18 \%)\end{array}$ \\
\hline & & & Cyberlaw & $\begin{array}{l}\text {-SAP Accounting } \\
\text { Applicns } \\
\text {-Distributed systems } \\
\text { - ERP:Systems Config } \\
\text { \& Use }\end{array}$ & $\begin{array}{c}\text { Business applica- } \\
\text { tions and e- } \\
\text { business }(16 \%)\end{array}$ \\
\hline
\end{tabular}


Another reason for variation in responses is size and resource availability. It was noted earlier that the two most prevalent forms of IT integration has been including the AIS course and development of the AIS concentration. "Large" institutions $(10,000-15,000)$ appear to have more responses in both categories, which may suggest that resource availability to employ faculty with the required specialization is a factor in the decision. However, two smaller accounting programs were able to offer the AIS concentration suggesting that initiative and focused resource allocation (to the areas that are seen as relevant to the program strategy) may make change a possibility. It is also of interest to note that "very large" institutions had a lower percentage of AIS concentrations than the "large" category. The constraints cited by Albrecht and Sacks (2000) in implementing changes in accounting education may particularly pertain to this category of institutions. These institutions may find it difficult to change because "accounting education is burdened by the hierarchy within universities. Before curricula changes can be made, approval must often be given by departmental and college curriculum committees, university administrators, and even boards of regents" (pp. 13).

A limitation of the study is that it uses course titles to proxy for course content. Therefore, it may not be descriptive of specific changes within traditional courses. ${ }^{3}$ Some colleges, for example, have begun to incorporate ERP systems into their traditional accounting courses. These may not be separately mentioned in course titles. However, considering that it would be in their interests to differentiate themselves from other programs (due to investments required), and different pre-requisites that may also be required, it would be likely that such differences are indicated in the title. In addition, changes to the curriculum are generally a continuous process and therefore replication of the study is not possible. To illustrate the problem, the initial data was collected in 2000 , and the sample was again updated in September 2001. Four colleges offering the AIS major were found to have made extensive changes to their curricula. There are additional limitations when working with Web sites, for example, the possibility of errors. This also makes it difficult to replicate studies. However, Web sites are no longer a novelty, and being in the public domain, it reflects the image of the institutions. It often forms a substitute for catalogs, and therefore, it is reasonable to assume that such Web sites provide a fairly reliable source of information.

\subsection{Conclusion}

The calls for change in accounting education began with the Big 8 Paper and the consequent setting up of the Accounting Education Change Commission. Rapid changes in the environment have resulted in erosion of enrollments, and lower quality of students in accounting programs. There are several suggestions made for improving accounting education. One option was a "combination degree", the integration of accounting with a related discipline. One such combination was an accounting/systems combination.

This paper specifically analyzed the course mix of several institutions that adopted the accounting/ information systems combination strategy. There were wide variations in the specific course mixes adopted by the institutions. These variations in the responses of institutions are in conformity with suggestions of the AACSB and the AAA Changing Environment Committee. The AAA Changing Environment Committee, for example, suggests that each college should develop a niche based on the needs of their constituents and that also reflects their individual strengths and needs.

These changes indicate that while there are challenges facing accountants, there are also opportunities to provide new and improved services. Accountants can develop for themselves an important niche in this information economy due to their intrinsic involvement with the transformation, analysis and communication of information. Mary S. Stone (2000), former president of the American Accounting Association, pointed out that "the more I have read and observed the changes occurring in the economy, the more I am convinced that rather than asking us to put ourselves out of business, those calling for change are pleading with us to take advantage of the opportunities the new economy offers" (pp. 2)

\subsection{Suggestions for Future Research}

Future areas of research and extensions of the study could examine changes in courses and course mixes to determine whether there are increases in the proportion of "internally generated" courses. Results could indicate ei- 
ther maturing (or stagnation) of research in AIS, needed to generate courses that have a separate identity from the traditional areas in accounting, and/or the smoothness of the transfer of research into pedagogy. Readers with comments or questions are encouraged to contact the authors via email.

\section{Endnotes}

1. The ISACA is an international organization with 18,000 members from 80 countries that represent all levels of information technology professionals.

2. Data on enrollment of business programs was unavailable from the web, and therefore, total undergraduate enrollment was taken to proxy for the size and resources of the programs.

3. It may be added that it is not the objective of this paper to investigate the content of individual courses, such as the AIS, which has been done in Groomer and Murthy (1996).

\section{References}

1. American Accounting Association, "Committee on the Future Structure, Content, and Scope of Accounting Education (The Bedford Report)," 1986.

2. _. "Perspectives on Education: Capabilities for success in the accounting profession (The Big 8 White Paper)," 1989.

3. _ _ Report of the Changing Environment Committee, "The Future Viability of Accounting Education." Sarasota, FL: AAA, 1998

4. _ Report of the Environmental Screening Committee, "The State of the Accounting and Business Environments and Effective Academic Responses Thereto," Sarasota, FL: AAA, 2000.

5. Albrecht, W. S. and R.J. Sacks, “Accounting Education: Charting the course through a perilous future.” Accounting Education Series, Vol. 16. American Accounting Association, 2000.

6. Arnold, V., and S. G. Sutton, "The future of behavioral accounting (information systems) research," Advances in Accounting Behavioral Research, 4, pp. 141-153, 2001.

7. Beresford, D. R. and T.L. Johnson, "Interactions between the FASB and the academic community," Accounting Horizons, December, pp. 108-117, 1995.

8. Bodnar, G. H., "Auditing information systems: Model curricula for information systems auditing," Internal Auditing, Jan/Feb, 40-45, 1999.

9. Bowling Green State University. http://www.cba.bgsu.edu/amis/programs/ISAC/isac.html [On-line]

10. Certified Information Technology Professional (CITP) Designation Handbook_(A guide to accreditation for the Certified Information Technology Professional). www.citp.aicpa.org [On-line]

11. Dickson, Michael R., “The CFO's e-survival guide: Will you be 'voted' out?” Ohio CPA Journal, Jul-Sep, pp. 27-29, 2001.

12. Groomer, S. M. and U. S. Murthy, "An Empirical Analysis of the Accounting Information Systems Course," Journal of Information Systems, fall, 1996.

13. Siegel, G. and J.E. Sorensen, "What corporate America wants in entry-level accountants," Management Accounting, September, pp. 26-31, 1994.

14. Siegel, G. and C.S. Kulesza, "The coming changes in management accounting education," Management Accounting, January, pp. 43-47, 1996.

15. Stone, M. S., "What will we teach?” Accounting Education News, fall, pp. 1-3, 2000.

16. Wallman, S. M. H., "The future of accounting and financial reporting, part IV: Access accounting," Accounting Horizons, June, pp. 103-116, 1997.

17. Williams, J. R., "Challenges facing accounting education,” The Practical Accountant, July, pp. 68-69, 2000 . 


\section{NOTES}

